\title{
IDŐJÁRÁS
}

Quarterly Journal of the Hungarian Meteorological Service

Vol. 123, No. 1, January-March, 2019, pp. 89-106

\section{Thermal seasons onset and length in Poland - a multiannual perspective on 1971-2010}

\author{
Michał Kitowski", Michał Marosz, and Mirosław Miętus \\ Faculty of Oceanography and Geography, University of Gdansk, \\ ul. Bażyńskiego 4, 80-309, Gdańsk, Poland \\ *Corresponding author E-mail: michal.kitowski@ug.edu.pl
}

(Manuscript received in final form February 12, 2018)

\begin{abstract}
The major aim of the research is to analyze the variability of thermal seasons characteristics (onset and length), at 7 stations in Poland during the 40-year-long period of 1971-2010. The analysis comprised the selection of the optimal method for season onset identification and the statistical analysis of the season onset and length characteristics, which was augmented with the interdecadal comparison of statistics using one-way analysis of variance (ANOVA). Also, it was investigated if the season onset type (late/normal/early) induces the season length distribution characteristics. The results show that the variability of the onset of thermal seasons is most pronounced in the case of summer and early spring. Summer also shows the tendency to occur faster, whereas autumn tends to start later. The interdecadal change of the thermal seasons length is clearly visible in the case of summer which length systematically increases and winter where the trend is reversed at most of the stations. The research also confirmed that for winter, early spring, and summer, the onset type clearly determines the distribution of the season length. Other seasons either show little variability or the differences appear only at some stations.
\end{abstract}

Key-words: thermal seasons, thermal seasons onset, thermal seasons length, air temperature, Poland

\section{Introduction}

A climate of an area can be described with the establishment of its seasonal structure (Woś, 1999). The onset, decline, and length of individual seasons are the indicators of climate's natural variability in annual cycle. Variability of the seasonal characteristics in the last century may indicate the occurring climate change (Kwaśniewska and Pereyma, 2004). 
Thermal seasons identification and investigation have long been on the agenda of Polish researchers and have a history of over 100 years. As early as in 19th century, Jastrzembski attempted the recognition of climatic seasons based on thermal thresholds however, using the phenological criterion. Romer (1906) utilized names of the seasons which we apply until today, but it was Merecki (1915) who can be considered the actual pioneer of such an approach. He identified six climatic seasons: winter, early spring, spring propper, summer, autumn propper and late autumn. The utilized thermal thresholds where $0{ }^{\circ} \mathrm{C}$, $5{ }^{\circ} \mathrm{C}$, and $10^{\circ} \mathrm{C}$, but they referred to the multiannual monthly average temperature (Nowosad and Filipiuk, 1998). Similar approach was presented by Bartnicki (1948). On the other hand, Wiszniewski (1960) claims that the proper approach is to identify as much as eight seasons in Poland with an additional $10{ }^{\circ} \mathrm{C}$ threshold. Such method was also acknowledged by Trybowska (1963) and Makowiec (1983). Another division was proposed by Hess (1965), but it was restricted to mountain areas with the assumption that the onset of the specific seasons can not be mutual for varying mountain ranges at the same altitude. He also proposed to use as much as 10 seasons. Woś (1999) claims that the identification of climatological seasons can not be the same globally, as this should be the result of chosen methodology and geographical location. The four seasons used in Scandinavian countries can serve as an example here (Czerneckis and Miętus, 2010). A research on thermal seasons in Hornsund seems to confirm the suitability of this approach (Kwaśniewska and Pereyema, 2004). Methods utilizing daily average temperatures lead to similar results, whereas the usage of monthly means, i.e., a simplified method, does not yield robust results. Such an approach may diverge substantially from the results obtained with other methods. Piotrowicz (2000) points out that while defining the date of thermal threshold crossings, multiannual monthly averages are used most often. It is assumed that, the monthly average temperature is much closer to the average daily temperature of the mid-day of a month, and the changes of the temperature are linear. Analytical approach here relies on the formulas devised by Gumiński (1950), which were subsequently widely used by others, e.g., Nowak (1967), Stopa (1968) or Czernecki and Miętus (2010). Stopa (1968), mentioned that the most precise way is to draw a course of multiannual daily averages. However, this method is rarely used as it is time-consuming and laborious as well as it is hard to collect the reliable data from longer periods. Piotrowicz (2000) used the TERPOR software in the process which was devised by Niedzwiedz and Limanówka (1992).

Samborski and Bednarczuk (2009) used the division into 8 seasons in the investigation of thermal seasons in Zamość. They counted the number of days above the defined thermal thresholds. In cases when the temperature fell below the tresholds in subsequent days, the authors calculated mean value from the period in question and finally assigned to the proper season.

Czernecki and Miętus (2010) used the utilised formulas proposed by Gumiński (1948) in the initial phase of their research on the dates of the onset of 
seasons in Poland. The authors compared this method with its modified version proposed by Michał Kowalewski in the Atlas of Climate of Poland by Lorenc (2005), mentioning that the results might be considered equal, as in the extreme cases the differences between the dates differ by one day. The applicability of Gumiński's formulas was also acknowledged by Skowera and Kopec (2008), when they used it to delimitate the economical and vegetation periods. Authors also point the cases with no thermal winter or summer. This is a problematic issue as it makes precise identification of the seasons length difficult. In such cases authors propose the approach of symmetric length of neighboring periods.

Czernecki and Miętus (2010) indicate that application of multiannual daily average temperatures for periods shorter than a dozen years is dubious. As they point out, this is due to the fluctuations of temperatures which can quickly oscillate of temperature ranges even three seasons. The solution proposed by the authors relies on the 7-day consecutive averages used to smooth the data. Also, they claim that the calculated indicators, which characterize the occurrence of thermal seasons, confirm their usefulness as climate change detection indicators. Rapp and Schönwiese (1994) point out that the exact date of the onset of thermal seasons and their temporal trends in Germany are assessed. Generally, a late autumn can be determined for the last 50 years, whereas spring seems to come earlier in many places. On principle, a prolongation of the warmer half of the year can be ascertained. Jaak and Rein (2000) analyzed the spatial and temporal variability of climatic seasons and phenological phases in Estonia. They used the days of onset and the duration of 8 climatic seasons and 16 spring and summer phenological phases at 23 stations in Estonia between 1946 and 1998. Using the thermal thresholds of $0{ }^{\circ} \mathrm{C}, 5{ }^{\circ} \mathrm{C}$, and $13{ }^{\circ} \mathrm{C}$. They argue that the $15^{\circ} \mathrm{C}$ temperature threshold is not a suitable criterion for the summer season in Estonia, as during extremely cold summers, the daily mean air temperature does not exceed this limit for longer period of time. Hiltunen et al. (2014) hypothesized that the ambient temperature and the timing of thermal seasons onset might associate with the suicide rate in Finland. As climatological data, they used daily mean, minimum, and maximum temperatures from the local weather stations at the Helsinki-Vantaa, Jyväskylä, and Oulu airports, the dates for the thermal seasons for each study area for each year, and the dates for the astronomical seasons. All the data were provided by the Finnish Meteorological Institute. Authors identified 4 thermal seasons (spring, summer, winter, and autumn) and have used the thermal thresholds of $0{ }^{\circ} \mathrm{C}$ and $10^{\circ} \mathrm{C}$. Other Finnish authors (Ruosteenoja et al., 2011) inferred the duration of the seasons and the growing seasons till the end of the 21 st century. They are using a high-resolution observational data set covering Finland and an average of the air temperature simulated by 19 global climate models. There are four thermal seasons in Finland expected in the elevated area of northwestern Lapland. Authors predict that under the A2 scenario, thermal winter will disappear in the southwestern part of the country before the period 2070-2099. 
In this paper an attempt was made to analyze the long-term (1971-2010) variability of the occurrence of the seasons (onset and length) at selected stations in Poland. The variability of characteristics was also analyzed in individual decades with the aim to identify the differences of seasons characteristics.

\section{Data and methods}

The analysis comprised the investigation of the general characteristics of the occurrence of the seasons, i.e., their beginning and cessation (and thus the length) with additional insight into tendencies/trends for the period 1971-2010.

The analysis concerns seven meteorological stations: Leba, Chojnice, Toruń, Łódź, Kielce, Tarnów, and Zakopane (Fig. 1). The used meteorological variable is the daily average air temperature $\left(t_{d}\right)$, which originates from the database of the Institute of Meteorology and Water Management - National Research Institute. The criteria for the station selection were as follows. The variability in the overall temporal structure of the occurrence and length of the seasons is the result of the different localization (in climatological context) of regions (Lorenc, 2005), therefore, the stations were chosen so that they cover all geographical regions, seacoasts, lakelands, lowlands, uplands, and mountain areas (Kondracki, 2002). The selected stations constitute a north-south transect through Poland (Table 1), which also reflects the variations in the incoming solar energy - a factor not to be neglected in the analysis of the thermal seasons variability.

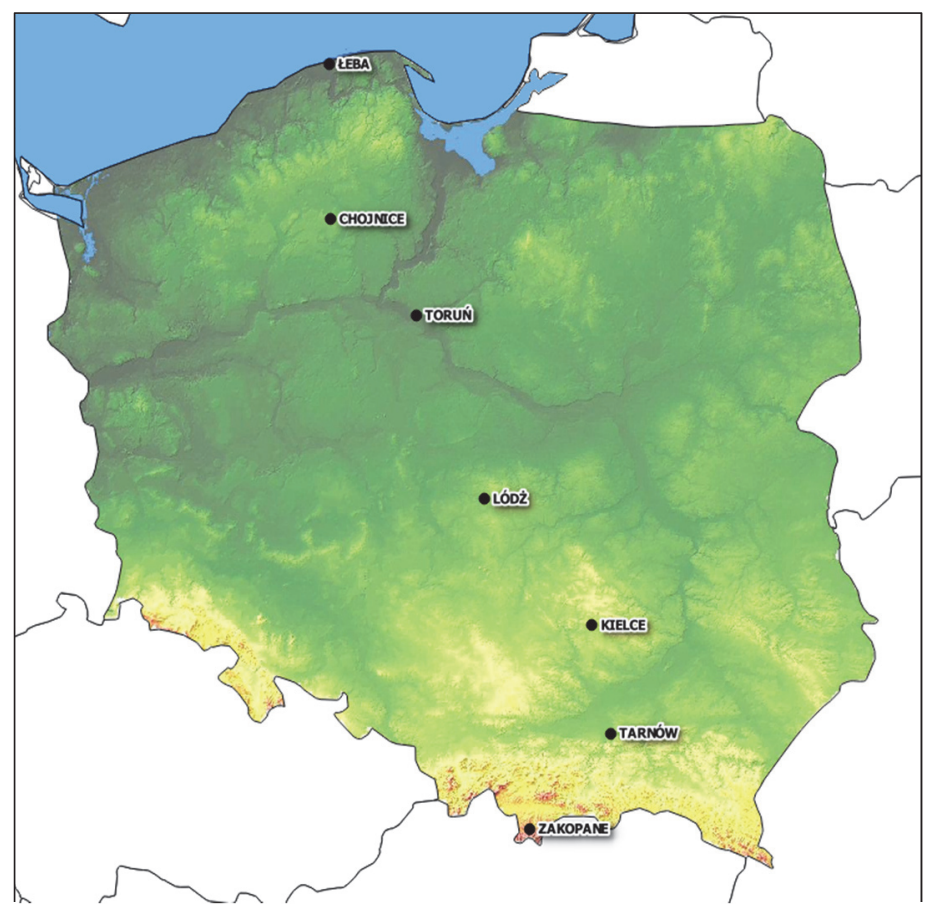

Fig. 1. Locations of the stations in Poland. 
Table 1. Coordinates and elevation ( $\mathrm{m}$ a.s.1.) of the stations

\begin{tabular}{lccc}
\hline \hline Name & Elevation & Latitude & Longitude \\
\hline \hline ŁEBA & 2 & $54^{\circ} 45^{\prime} \mathrm{N}$ & $17^{\circ} 32^{\prime} \mathrm{E}$ \\
CHOJNICE & 164 & $53^{\circ} 42^{\prime} \mathrm{N}$ & $17^{\circ} 33^{\prime} \mathrm{E}$ \\
TORUŃ & 69 & $53^{\circ} 02^{\prime} \mathrm{N}$ & $18^{\circ} 35^{\prime} \mathrm{E}$ \\
LÓDŹ & 187 & $51^{\circ} 44^{\prime} \mathrm{N}$ & $19^{\circ} 24^{\prime} \mathrm{E}$ \\
KIELCE & 260 & $50^{\circ} 49^{\prime} \mathrm{N}$ & $20^{\circ} 42^{\prime} \mathrm{E}$ \\
TARNÓW & 209 & $50^{\circ} 02^{\prime} \mathrm{N}$ & $20^{\circ} 59^{\prime} \mathrm{E}$ \\
ZAKOPANE & 855 & $49^{\circ} 18^{\prime} \mathrm{N}$ & $19^{\circ} 57^{\prime} \mathrm{E}$ \\
\hline
\end{tabular}

Identification of the onset and end of the seasons was multistage procedure and the used thermal thresholds were common Romer-type tresholds, i.e., $0{ }^{\circ} \mathrm{C}$, $5^{\circ} \mathrm{C}$, and $15^{\circ} \mathrm{C}$. Daily average temperature $\left(\mathrm{t}_{\mathrm{d}}\right)$ was used (Romer, 1938) as a thermal indicator. Such an approach yields six seasons (Table 2).

Table 2. The studied thermal seasons and the air temperature thresholds utilized in the procedure of identification

\begin{tabular}{lc}
\hline \hline Season & $\mathbf{t}_{\mathrm{d}}$ threshold values \\
\hline \hline early spring (ESPRING) & $0.0{ }^{\circ} \mathrm{C}<\mathrm{t}_{\mathrm{d}} \leq 5.0^{\circ} \mathrm{C}$ \\
spring (SPRING) & $5.0{ }^{\circ} \mathrm{C}<\mathrm{t}_{\mathrm{d}} \leq 15.0^{\circ} \mathrm{C}$ \\
summer (SUMMER) & $\mathrm{t}_{\mathrm{d}}>15.0{ }^{\circ} \mathrm{C}$ \\
autumn (AUTUMN) & $5.0{ }^{\circ} \mathrm{C}<\mathrm{t}_{\mathrm{d}} \leq 15.0{ }^{\circ} \mathrm{C}$ \\
early winter (EWINTER) & $0.0{ }^{\circ} \mathrm{C}<\mathrm{t}_{\mathrm{d}} \leq 5.0{ }^{\circ} \mathrm{C}$ \\
winter (WINTER) & $\mathrm{t}_{\mathrm{d}} \leq 0.0{ }^{\circ} \mathrm{C}$ \\
\hline
\end{tabular}

The selection of methodological approach is the crucial one when performing the seasons' onset identification, as differing methods yield varying results, and thus, can limit the possibility of further application.

Data originating from Institute of Meteorology and Water Management National Research Institute (IMGW-PIB) on average daily air temperature $\left(t_{d}\right)$ were checked for completeness. In the first phase of the study, an attempt was made to determine the thermal seasons based on variability of the long-term average daily air temperature. This method, although indicated in the literature 
as the most thorough, proved to be too problematic due to the multiple passing of temperature across the thermal thresholds. In order to eliminate high frequency oscillations, it was decided to use a triangular filter also used for seasons' onset detection by Nowosad and Filipiuk (1998). Filters of length 3, 5, 7, 9, and 13 were used. However, the results still proved to be unsatisfactory. The frequency of the oscillation of the $t_{d}$ curve in the vicinity of the threshold temperatures was still too high even for the 13-element filter (Fig. 2). Additionally, the use of the filter involved the loss of some data at the beginning and the end of the analyzed time series.

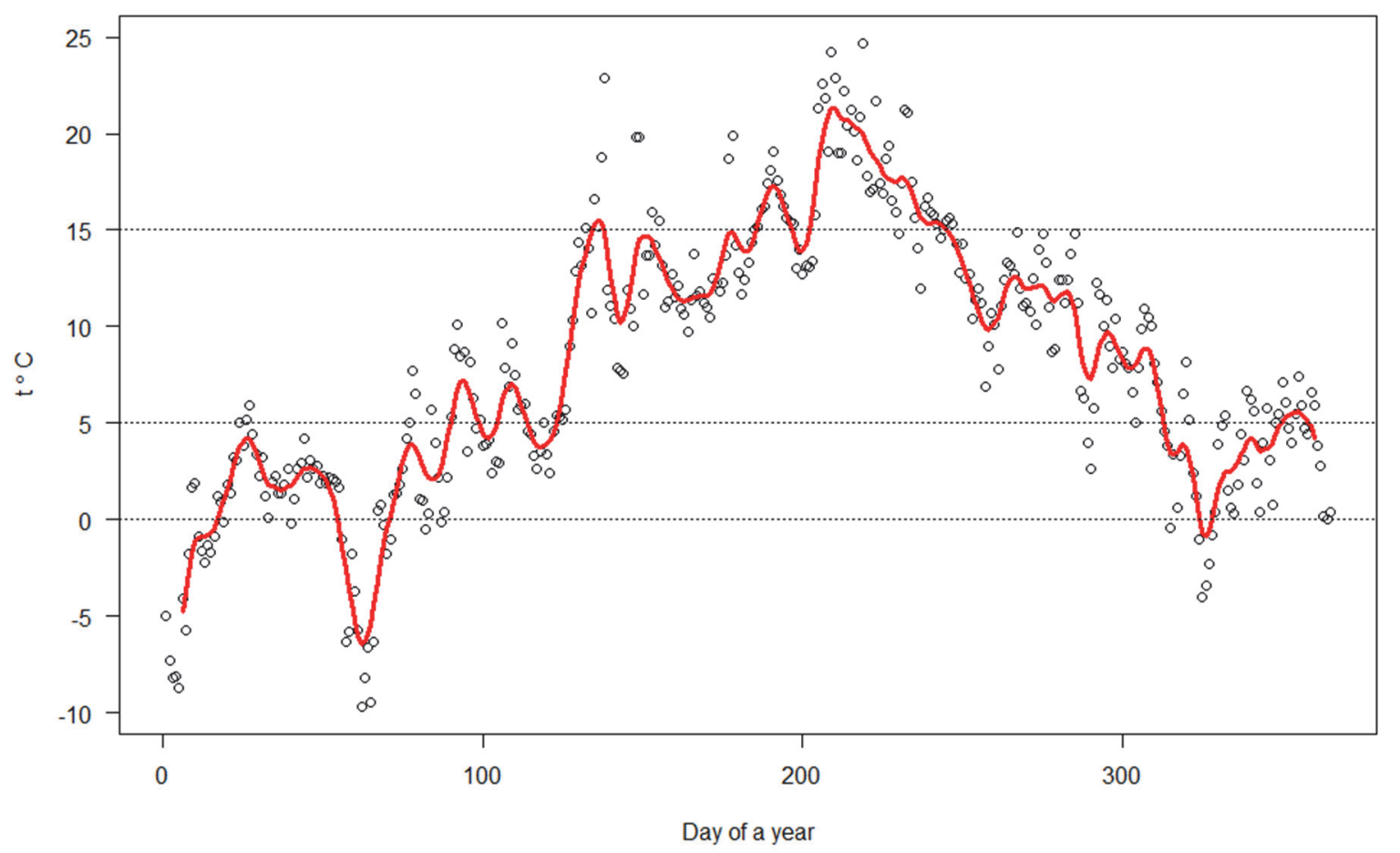

Fig. 2. Annual course of the daily average air temperature (t) with 13 -element triangle filter (red line) in Leba in 1971. Temperature thresholds $\left(0{ }^{\circ} \mathrm{C}, 5{ }^{\circ} \mathrm{C}\right.$, and $\left.15^{\circ} \mathrm{C}\right)$ are marked with dotted lines.

Next, a finally satisfactory attempt comprised the utilization of 10-day (decadal) and 5-day (pentad) averages. Of course, the last decade and pentad length depend on the month. The overall assumption was that each month has 30 days, and the values of averages are assigned to the midday of the decades and pentades as 5th, 15th, and 25th and 3rd, 8th, 18th, and 28th day, respectively. Such approach allowed the detection of the date of crossing of temperature thresholds. The detection itself was automated with the usage of a linear interpolation scheme. 
Dates were assigned to the onset of the seasons. Comparison of those methods ( 5 versus 10 days averages approach) revealed that the differences between the onset dates were not significant. Additionally, for the analysis with 5 -day averages, the threshold crossing problem occurred too often. Finally, the decision was made to use the 10-day (decadal) averages in the procedure of the season onset and end identification.

The growing number of the cases of years without thermal winter or summer resulted in the impossibility to identify the length of those seasons. It was decided to use the approach proposed by Miętus and Czernecki (2010) which forces the symmetrical length of the spring and autumn (in case of no summer) and has an analogous approach in the case of early winter and early spring (in the case of no thermal winter).

To provide a more formal statistical workframe, the analysis of the decadal variability of the season's onset date and its length was further augmented with the application of ANOVA analysis (Balicki and Makać, 2007), thus allowing the identification of statistically significant differences in the season's characteristics in decades. Due to relatively small sample size in compared decades (10), it has been decided to treat $\alpha=0.1$ as a satisfactory level to acknowledge significant changes. Also, the relatively high variability of the analyzed indices within decades should be mentioned here as a potential impediment to the recognition of significant differences.

In the course of analysis of thermal seasons' onset, an additional variable was calculated indicating if the onset of the season was early, normal, or late. This was performed on the basis of the comparison of the season onset date $(\mathrm{K})$ in a given year with the onset date quantiles calculated as multiannual characteristic (Table 3). The aim of such approach was the identification of possible links between the onset (late, normal, early) and the length of the season.

Table 3. Scheme of season onset classification

\begin{tabular}{lc}
\hline \hline Season onset type & Criterion \\
\hline \hline early & $\mathrm{D}<\mathrm{K}_{0.33}$ \\
normal & $\mathrm{K}_{0.33}<\mathrm{D}<\mathrm{K}_{0.66}$ \\
late & $\mathrm{D}>\mathrm{K}_{0.66}$ \\
\hline
\end{tabular}

where $\mathrm{D}$ is the onset of a season, $\mathrm{K}_{0.33}$ is the multiannual quantile 0.33 of the seasons onset, $\mathrm{K}_{0.66}$ is the multiannual quantile 0.66 of the seasons onset, and the $\mathrm{D}$ and $\mathrm{K}$ are expressed as consecutive days in Julian year. 


\section{Results}

\subsection{Seasons' onset}

In the period 1971-2010, the onset of thermal early spring occurs in February at all analyzed stations, except Zakopane. On average, at the earliest, the early spring was observed at Torun and Tarnów stations (February 11) and at the latest at Zakopane station (March 8). Thus, the range between the onset dates of the thermal early spring amounts to 25 days (Fig. 3). Moreover, the earliest beginning of the early spring can be dated at December 2, 1994 in Tarnów, whereas the latest beginning of the season was on March 8, 2004 in Zakopane. During the whole analyzed period, the beginning of the early spring was noticed at the latest in Zakopane.

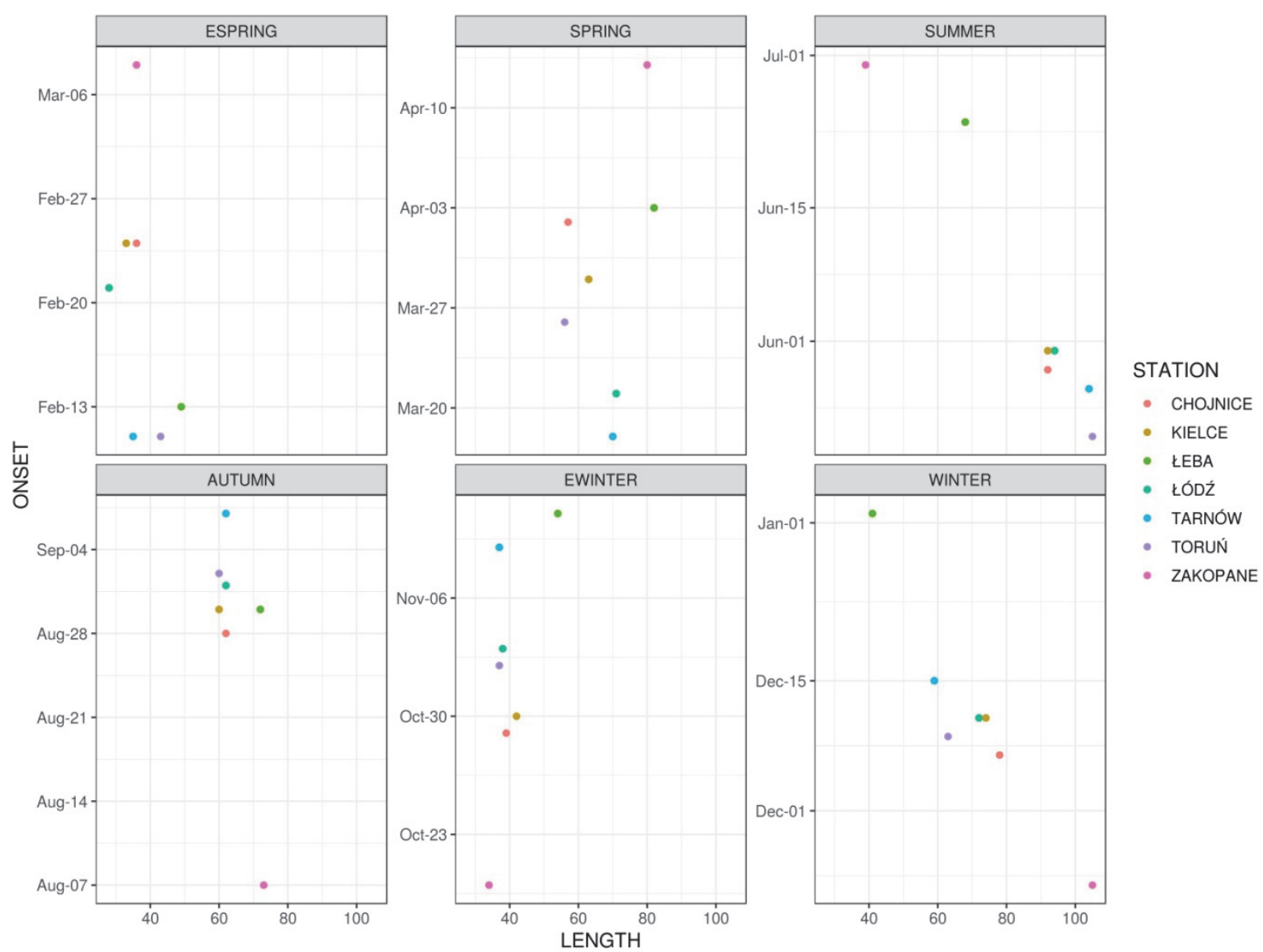

Fig. 3. Average length (days) and onset (month - day) of thermal seasons at selected stations in Poland (1971-2010). 
On average, the thermal spring began at the earliest at Tarnów station (March 18), whereas at the latest its beginning could be observed at Zakopane station (April 13). Hence, the range between the beginning dates of the thermal spring builds up to nearly a month. Taking into consideration the analyzed period, the thermal spring began at the earliest at Tarnów and Łeba stations in 1990 (January 24). At the latest it was noticed at Zakopane station in 1980 (May 12). It can be also observed that the thermal spring occurs at the latest at the Zakopane station.

On average, the beginning of thermal summer can be observed at the earliest in Torun (May 22), whereas at the latest it was noticed in Zakopane (June 30). It can be assumed that the difference between the beginning dates of the season is 39 days. In most cases the thermal summer began at the latest in Zakopane. An interesting fact, that during the analyzed period, the thermal summer did not occur at the Zakopane station (1978, 1990, 2000).

On average, the thermal autumn began at the earliest in Zakopane (August 7). At the latest, however, the thermal autumn can be noticed in Torun (September 2) and Łódź (September 1) (Fig. 3). Hence, it can be calculated that the difference between the earliest and latest beginning dates of thermal autumn amounts to 30 days. Taking into consideration the whole analyzed period, the thermal autumn occurred at the earliest in Zakopane and at the latest in Tarnów. The earliest occurring of thermal autumn can be dated back to 1985 at the Łódź station (June 6). At the latest, it occurred at the Chojnice station in 1975 (September 28).

In most cases, the thermal early winter began at the earliest in Zakopane (October 20) and at the latest at the Łeba station (November 11) (Fig. 3). Thus, the difference between the beginning dates of thermal early winter at those two stations equals 30 days. The earliest occurring of the early winter in the analyzed period can be dated back to 1972 in Zakopane (September 24). The latest one was noticed in Łeba in 2002 (January 17). Furthermore, there is the tendency of early winter occurring later every year.

On average, the earliest beginning date of the thermal winter was noticed in Zakopane (November 23). The latest beginning date, however, was observed in Łeba (January 2). Thus, the difference between the two extreme average beginning dates of thermal winter is 52 days. At the earliest, the thermal winter occurred in Zakopane in 1973 (October 10) and at the latest in Leba in 2000 (February 21). The thermal winter in the analyzed period can be marked by the tendency of occurring later every year. Moreover, it was noted that the thermal winter did not occur twice in the analyzed period, namely in 1974 in Łeba and in 2006 in Tarnów.

Taking into consideration the onset dates of the thermal seasons at the analyzed stations, some regularities can be observed. It can be assumed that the changes in the occurring of the thermal seasons' beginning dates are most likely 
to happen at the stations located northernmost and southernmost, namely at the seaside station in Łeba and the mountain station in Zakopane.

Moreover, it can be assumed that at the Zakopane station warm thermal seasons (early spring, spring, summer) occur at the latest among all analyzed stations. However, cold thermal seasons (autumn, early winter, winter) occur in Zakopane at the earliest. Undoubtedly, it is caused by the insolation and orography of the region, as well as by the relatively long snow cover maintenance. Furthermore, the thermal spring is the season that can be marked by the tendency to occur earlier every year.

Long term variability has been described with the usage of decadal means of the thermal seasons' onset dates (Fig. 4). Early spring in Chojnice, Tarnów, and Zakopane exhibits small variability with about 4 days differences between the decades. Average onset date in Zakopane fall, at the first decade of March and varies only by 1-2 days. In Tarnów, the onset is in the first half of February and the inter-decadal range is 9 days. The earliest onset occurred in the decade of 1991-2000. Other stations (Łeba, Chojnice, Toruń, and Łódz) exhibit significant shift in the early spring onset date in the 1991-2000 decade. The difference is about 30 days which is accompanied with the latter return to dates observed in the first two decades of the research period. This is most visible in the case of Łeba, where the shift between the decades of 1991-2000 and 20012010 was nearly 30 days.

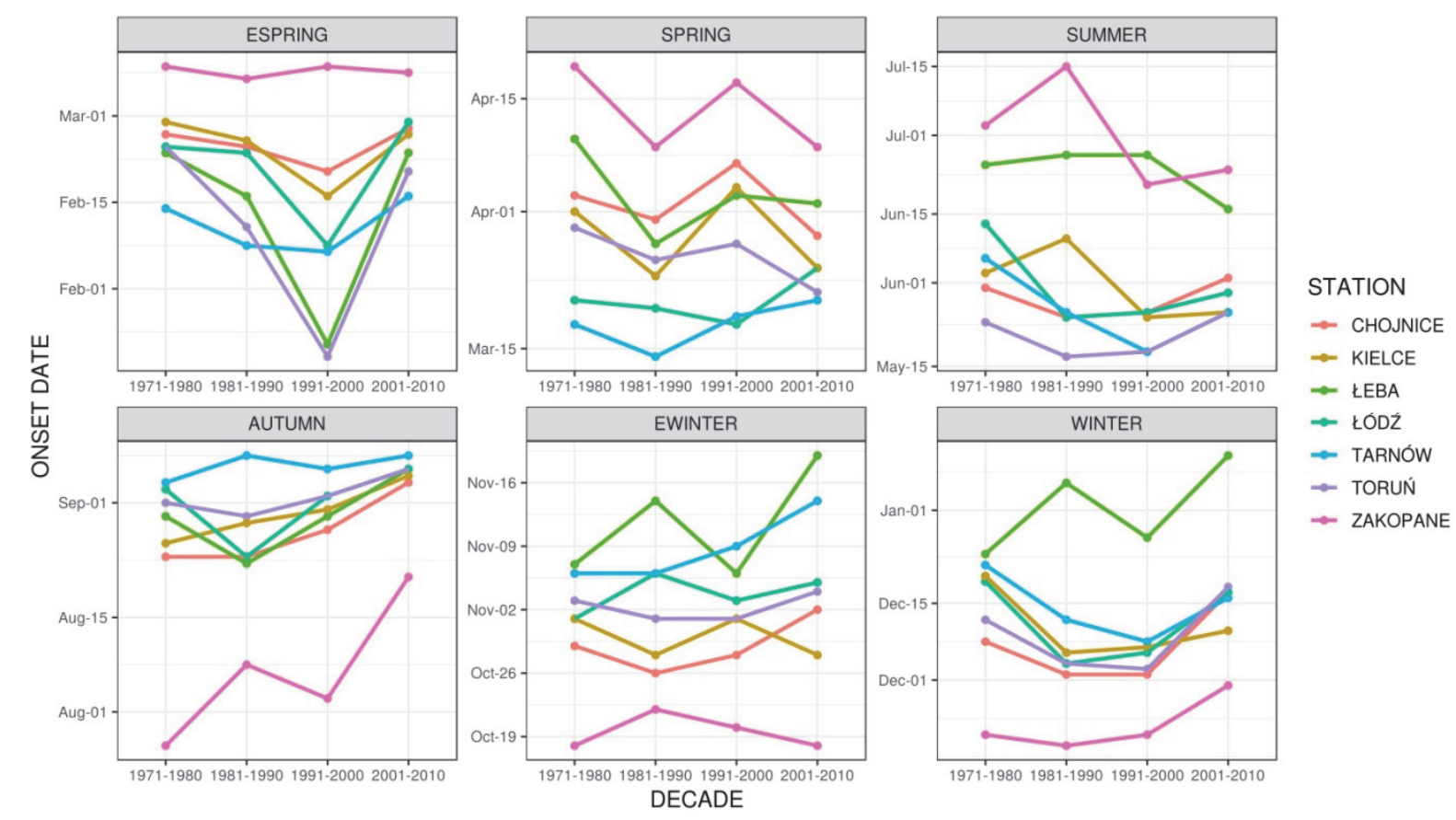

Fig. 4. Average date of the onset (month-day) of thermal seasons in decades at selected stations in Poland (1971-2010). 
In case of spring, there is a visible tendency to the earlier occurrence of this season. This trend has marked fluctuations. This is most clearly presented in case of Kielce and Zakopane. The exception are Tarnów and Lódz, where the thermal spring from (March 14) occur consistently later (March 21) int he decade 1981-1990.

The thermal summer occurs earlier. This is especially visible at Zakopane, Kielce, and Łódz. The difference between the 1981-1990 and 2001-2010 decades is nearly 14 days. Also, at other stations (except Toruń), the thermal summer shows the tendency to start earlier. However, the last decade (20012010) shows some signs of slowing down of this trend. It may be stated that earlier occurrence of thermal summer can constitute a sign of global warming.

The thermal autumn at all analyzed stations tends to start later. At most of the stations, the overall change between decades is about 8 days. Zakopane reveals the most significant change with the shift of 25 days between the 19711980 and 2001-2010 decades.

The thermal early winter (especially at the Łeba and Chojnice stations) in the last decade is marked by a tendency of later occurring. Collaterally, the average time of the thermal early winter occurring in 2000-2010 at the Eódź and Chojnice stations is shorter by 30 and 20 days than in the previous decade, respectively.

The thermal early winter in Łeba is characterized by fluctuations of the onset date with the general tendency to occur later. The total difference equals 12 days. Also, in Tarnów this season reveals a consistent trend to occur later with a total change of 8 days. Other stations do not exhibit apparent tendencies, and the early winter onset falls on the break of October and November. In Zakopane early winter starts between the 18th and 22nd days of October.

The inter-decadal variability of the onset of the thermal winter can be well observed in case of Łeba, Chojnice, and Zakopane. In Łeba the onset tends to occur later with a 18 days difference between the marginal decades. The earliest starting date of the thermal winter In Zakopane in November and the overall onset shift is 11 days. At the other stations the earlier occurrence of winter is in the two middle decades of the research period: 1981-1990 and 1991-2000, and relatively rapid shift occures toward the later onset during the last decade (from 6 to 15 days). The analysis was aided with the application of the ANOVA model with decades as a factor (Table 4). Only in autumn, the onset dates differ significantly between decades at 3 stations: Chojnice, Łeba, and Zakopane. Zakopane exhibits significant differences in summer and Łeba in early spring. This suggests that the variability of seasons onset dates do not vary between the decades at least with respect to the average onset. 
Table 4. ANOVA significance test results for the season onset types. Statistically significant differences (at alpha $=0.1$ ) are marked with "+" sign.

\begin{tabular}{|c|c|c|c|c|c|c|}
\hline Station & ESPRING & SPRING & SUMMER & AUTUMN & EWINTER & WINTER \\
\hline CHOJNICE & & & & + & & \\
\hline KIELCE & & & & & & \\
\hline ŁEBA & + & & & + & & \\
\hline ŁÓDŹ & & & & & & \\
\hline TARNÓW & & & & & & \\
\hline TORUŃ & & & & & & \\
\hline ZAKOPANE & & & + & + & & \\
\hline
\end{tabular}

\subsection{Seasons' length}

The average duration of thermal summer shows the tendency of elongation (Fig. 5, Table 5). In case of Łeba, Kielce, and Zakopane, one can observe an increasing trend. Moreover, it has been noted that in Torun and Tarnów, thermal summer lasts the longest, when compared to all analyzed stations.

Table 5. Average length (days) of thermal seasons at selected stations in Poland 1971-2010

\begin{tabular}{ccccccc}
\hline \hline STATION & ESPRING & SPRING & SUMMER & AUTUMN & EWINTER & WINTER \\
\hline \hline ŁEBA & 49 & 82 & 68 & 72 & 54 & 41 \\
CHOJNICE & 36 & 57 & 92 & 62 & 39 & 78 \\
TORUŃ & 43 & 56 & 105 & 60 & 37 & 63 \\
ŁÓDŹ & 28 & 71 & 94 & 62 & 38 & 72 \\
KIELCE & 33 & 63 & 92 & 60 & 42 & 74 \\
TARNÓW & 35 & 70 & 104 & 62 & 37 & 59 \\
ZAKOPANE & 36 & 80 & 39 & 73 & 34 & 105 \\
\hline
\end{tabular}

According to a study of the Institute of Meteorology and Water Management (IMGW) in Kraków, Tarnów is considered to be the Polish „heat pole”. The $\mathrm{IMGW}^{1}$ (2000) study includes data from the period 1977-2006, which is concurrent with the period analyzed in the present paper. Furthermore, the findings of the present study are also coincident with those of the IMGW study. One of the findings is that the thermal summer is stated to last the longest in

\footnotetext{
${ }^{1}$ Instytut Meteorologii i Gospodarki Wodnej
} 
Poland. The reason of the aforementioned situation might be a relatively pronounced exposure to sun in Poland (the average year insolation equals 1573 hours), the influence of the mountain foehn wind (Tatra Mountains) and the predominant west and south advection. The thermal winter shows, however, completely different tendency, when compared to the thermal summer. The most illustrative example is Łeba station, where the thermal summer is becoming longer over decades, whereas the thermal winter is shortening significantly (especially in the period of 1971-2000).

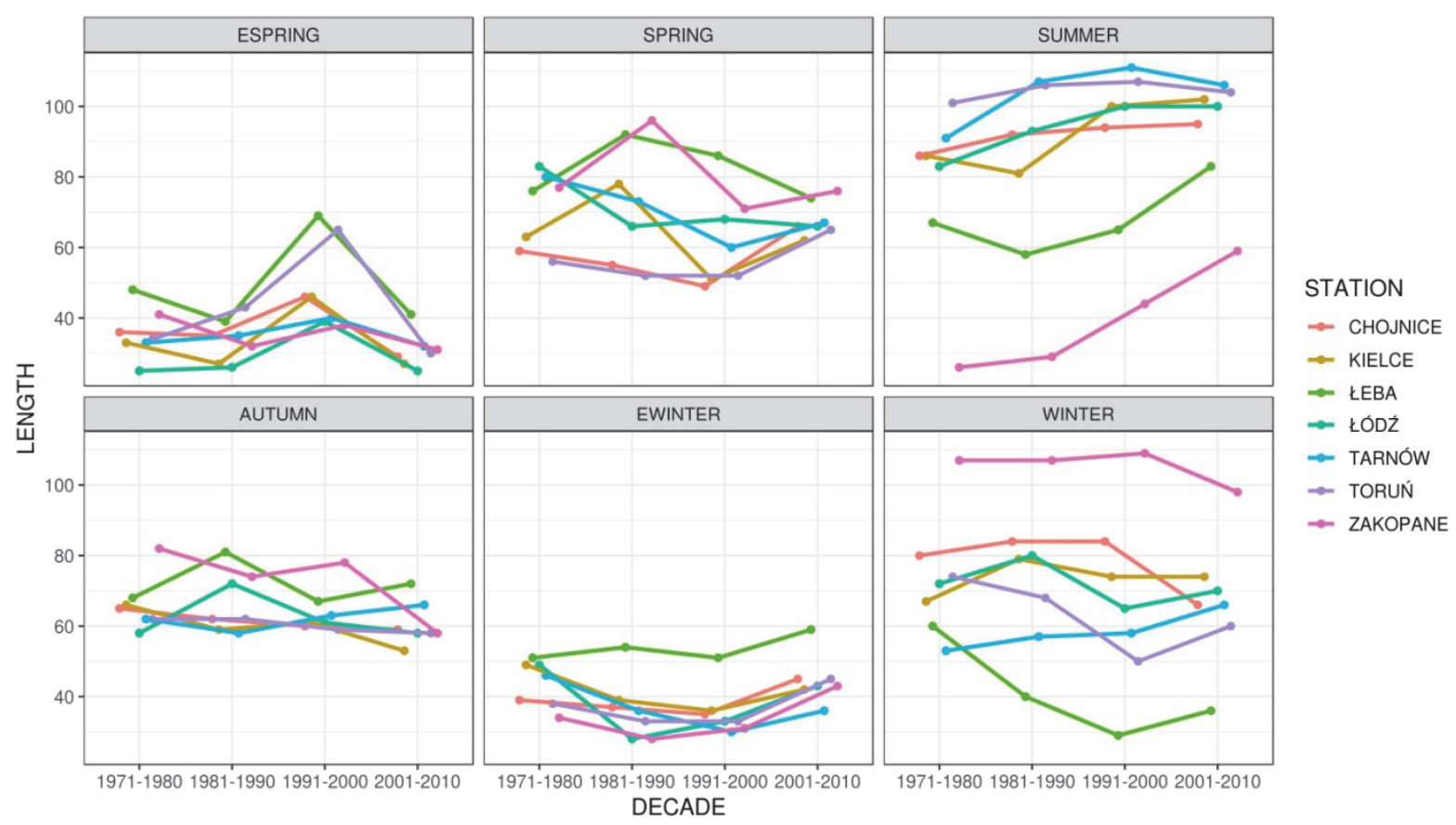

Fig. 5. Length (in days) of the thermal seasons at selected stations in Poland int he period 1971-2010.

The variability of the thermal winter is explicitly visible at the Chojnice station, where the average thermal winter duration has shortened by circa 14 days when compared to the previous decades. It can be also observed at the Zakopane station, where the thermal winter, for the first time, lasted less than 100 days in the decade from 2001 to 2010.

Furthermore, Tarnów station can be characterized by the fact that it is the only one among all the analyzed stations where thermal winter duration is successively lengthening. The ANOVA test suggests (Table 6) that in summer the length of this season had significant differences in mean in the different decades in Kielce, Łeba, Tarnów, and Zakopane. In spring the differences in thelength differed significantly only in Kielce and for early spring in Leba and Torun. 
Table 6. ANOVA results for season lenght versus decade setting at selected stations in Poland in the period 1971-2010. Statistically significant differences between decades (at alpha $=0.1$ ) are marked with "+" sign

\begin{tabular}{|c|c|c|c|c|c|c|}
\hline Station & ESPRING & SPRING & SUMMER & AUTUMN & EWINTER & WINTER \\
\hline \multicolumn{7}{|l|}{ CHOJNICE } \\
\hline KIELCE & & + & + & & & \\
\hline ŁEBA & + & & + & & & \\
\hline \multicolumn{7}{|l|}{ ŁÓDŹ } \\
\hline TARNÓW & & & + & & & \\
\hline TORUŃ & + & & & & & \\
\hline ZAKOPANE & & & + & & & \\
\hline
\end{tabular}

\subsection{Seasons' onset date versus duration}

The onset characteristics (early/normal/late) of the season may determine the length of the season to some extent (Fig. 6). The general rule that can be acknowledged is the earlier the onset, the longer the season's duration. This, however, manifests itself clearly only in certain seasons and usually can be blurred by the dispersion if the data values are around the mean. In case of early spring, those differences are clearly visible at all stations There is a visible shift towards longer duration with the earlier onset. This, however, is not uniform at all the stations. It is mostly visible in the northern part of Poland (Leba, Chojnice), where the difference in length between the late and early onset is nearly 60 days. There is no apparent (about 10 days) difference in length in case of the late/normal pair. Those differences tend to diminish southward and in Tarnów and Kielce the late/early discrepancy is about 35 days. Generally, the late onset of the season results in a very short season duration with mean values ranging from 15.6 days in Tarnów to 26.4 days in Łeba and 28.2 days in Torun. The differences in case of the early/normal/late onset comparison are the smallest in Zakopane.

In spring, the length duration differences are much less indicated and tend to express themselves only in the northern Poland (Łeba and Chojnice) and Zakopane with means in Leba ranging from 69.7 days (late onset) to 93.9 days (early onset). In central Poland, despite the fact the that differences in mean length values are recognisable, the flattening of the distributions makes those hardly recognizable. 


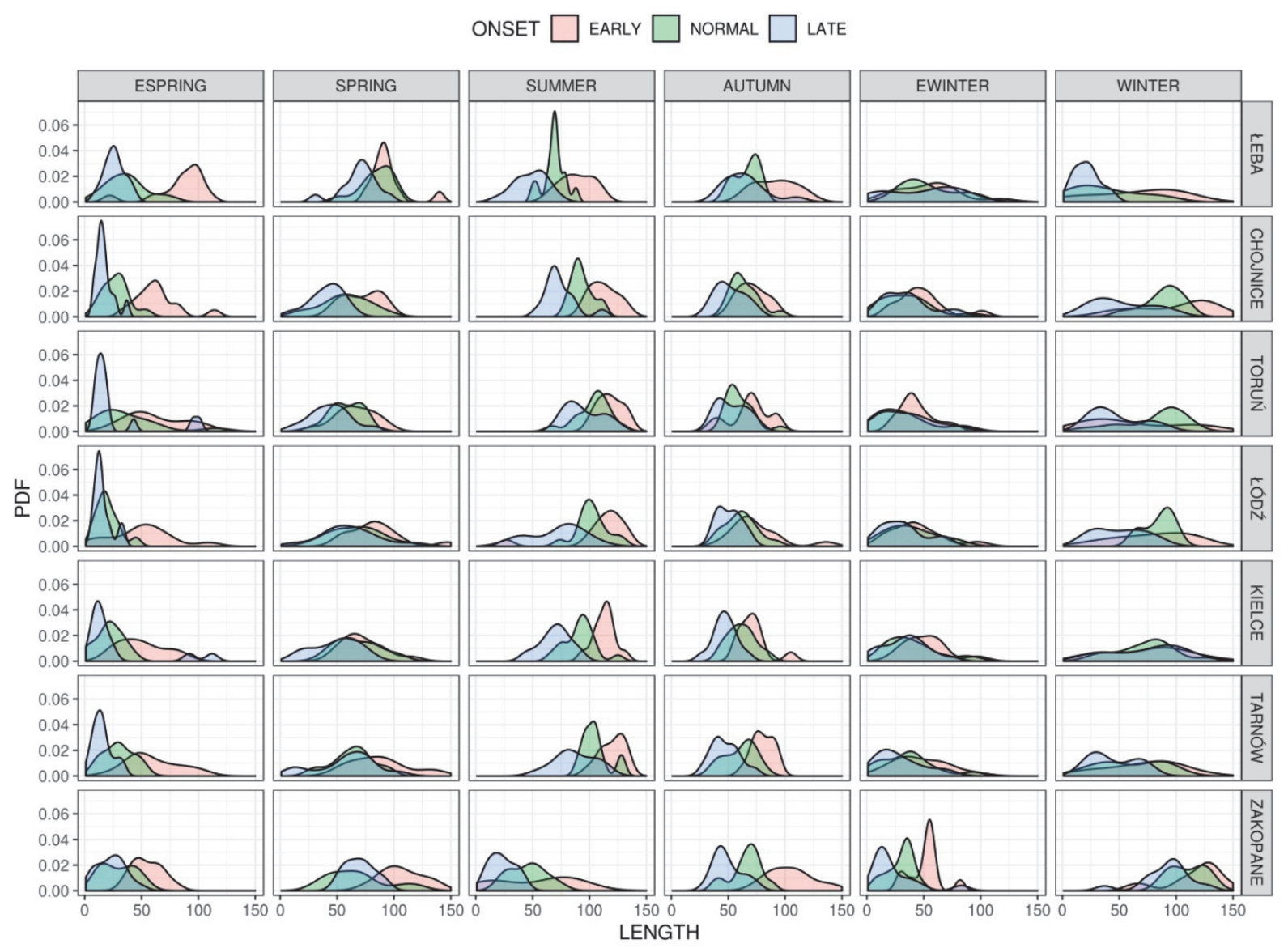

Fig. 6. Kernel density estimates for the length of the thermal seasons versus their onset characteristics at selected stations in Poland in the period 1971-2010.

Summer is another season when the onset determines the duration to a great extent. This is manifested not only in the shift of the mean season length, but also in the higher concentration of the values around the mean. The difference in length between the early/late onset is ranges from 23 in Torun to 41 days in Łeba and 43 in Kielce.

Autumn reveals slightly smaller differences than summer. Generally, at most stations from northern and central Poland, the differences in the mean season duration between the early and late onset, only in Leba exceed 25 days (27), while at the other stations they vary from 15 days in Torun to 24 in Kielce. The differences exceed 30 days only in Carpathian Mountains in Tarnow and Zakopane (33 and 55 respectively).

The early winter slightly resembles the spring with small differences in mean season length especially in Łeba (5 days) and Torun (10 days). Higher differences are recorded in Kielce and Tarnów (18 and 19 days, respectively). Also, here one can notice greater dispersions, which effectively diminishes the importance in the mean differences. This picture is somehow different only in Zakopane. Here the difference in mean length between early and late onset equals to 28 days which is 
unprecedented at any other station for this season. Also, the dispersion of the season's length distribution is much less pronounced here.

In winter the differences in seasons' length are the most pronounced in northern Poland, where in Leba and Chojnice they exceed 40 days (44 and 45 days, respectively). In Torun, the difference is only 15 days with a visibly shifted normal onset length towards longer duration (the mean is 20 days higher than in the case of the early onset). This feature is also present in Łódz (4 days longer than for the early onset). In Kielce, there is virtually no difference between the length means (the range is 0.4 days). In Tarnow and Zakopane, the difference between the early/late onsets is quite similar and equals to 25 days.

\section{Discussion and summary}

The utilized method allowed unequivocal determination of the onset (and thus, duration) of the thermal seasons in Poland. The analyzed period in the aforementioned work (Skoweraand Kopeć, 2008) concurs with the period studied in the present research. Comparison of the onset dates of the thermal periods at the Tarnów station show that the differences do not exceed 3 days (in spring), thus the resulting outcome may be that there is no significant difference (especially in long term analysis) between the decadal approach (utilized in the present research) and simpler methods utilizing monthly averages. Other authors used area average temperatures in the determination of the seasons onset for broader regions. To indicate the thermal seasons in the area of coast and highland, Czernecki and Miętus (2010) have used the area average obtained on the basis of the Alexanderson formula. To indicate the onset dates of the thermal seasons, the authors have used two methods, namely: the method proposed by Gumiński concerning the increase and decrease of temperature based on monthly averages, and the method utilizing weekly consecutive means. The analysis was applied to the 1951-2008 period. The authors have used the division to 6 thermal seasons, which is concordant with our research.

In case of Kielce versus Highland area, the obtained average onset dates of the thermal seasons differ by 7 days in the case of early spring, 1 day in the case of spring, 3 days in the case of summer, 4 days in the case of autumn, 8 days in the case of early winter, and 7 days in the case of winter. For Leba station the results show similar differences. Average beginning dates of the thermal seasons differ from each other by 8 days in the case of early spring, 5 days in the case of spring, 6 days in the case of summer, 7 days in the case of autumn, 0 days in the case of early winter, and 3 days in the case of winter. Taking the differing approaches into consideration (the longer period of analysis in the study of Czernecki and Miętus (2017)), it can be stated that the findings of both works are relatively similar.

All in all, the beginning dates of the thermal seasons indicated in the present study are concurrent with those obtained by other authors. The greatest concurrence 
can be found in the beginning dates of the thermal seasons for Tarnów station, which were compared with the dates indicated by Skowera and Kopeć (2008). It is worth mentioning, that all analyzed works used in the present comparison have implemented various methodologies and focused on different periods.

The analysis of seasons onset and length in 1971-2010 in Poland has allowed us to observe some regularities. In 1991-2000, the average early spring onset at all stations except Zakopane occurred earlier comparing to the 19811990 period. In addition, in 1991-2000, the average duration of early spring has been the longest one. The aforementioned situation coincides with the average later spring onset in 1991-2000 and its relatively short duration. The thermal summer is the season that shows visible tendencies for earlier onset and lengthening of its duration. It can be particularly well shown on the basis of the stations located in the north (Leba) and in the south (Kielce and Zakopane). Łeba and Zakopane can be also characterized with the latest summer onset as compared with all the other stations. It can be influenced by the proximity of the Baltic Sea in the north and the altitude of Zakopane (above $900 \mathrm{~m}$ a.s.l.). Moreover, the thermal autumn can be characterized by a progressively later onset in the whole area of Poland. The aforementioned situation is clearly illustrated by the example of Zakopane, where the difference between the average thermal autumn onset between the decades 1971-1980 and 2001-2010 equals to 25 days. The influence on the shift of thermal autumn onset has been certainly exerted by a progressively lengthening the thermal summer duration. The length of thermal autumn does not show any noteworthy tendencies. The thermal early winter is the season that can be characterized by the averagely shortest duration when compared with the other seasons. At the Leba, Torun, Chojnice, Łódź, and Tarnów stations, the thermal early winter shows the tendency to occur progressively later, whereas at the Kielce and Zakopane stations, the situation is quite contrary. Variability in the thermal winter onset and length, exactly as in case of the thermal summer, can be clearly seen at the stations most distant to each other. The progressively later thermal winter onset is coincident with its progressively shorter duration at the Leba, Chojnice, Torun, and Zakopane stations. On average, the thermal winter begins at the latest in Łeba, and it also lasts for the shortest period (the average minimum of 20 days in 1991-2000). On average, thermal winter begins at the earliest in November at Zakopane station. Zakopane is also the station, where the thermal winter lasts for the longest period (over 100 days).

\section{References}

Balicki, A. and Makać, W., 2007: Metody wnioskowania statystycznego, Wydawnictwo Uniwersytetu Gdańskiego. (In Polish)

Bartnicki, L., 1948: O porach roku i o osobliwościach klimatu Polski, Gazeta Obserwatora Państwowego Instytutu Hydrologiczno-Meteorologicznego, Warszawa, I, 4, 1-6. (In Polish) 
Czernecki, B. and Miętus, M., 2010: Wstępna analiza występowania i zmienności termicznych pór roku w wybranych regionach Polski na przykładzie Pasa Pobrzeży Południowobałtyckich i Wyżyn Polskich, Klimat Polski na tle Klimatu. Warunki termiczne i opadowe. Bogucki Wydawnictwo Naukowe. 15,. 9-26. (In Polish)

Czernecki, B. and Miętus, M., 2017: The thermal seasons variability in Poland, 1951-2010. Theor. Appl. Climatol. 127, 481-493. https://doi.org/10.1007/s00704-015-1647-z

Gumiński, R., 1948: Próba wydzielenia dzielnic rolniczo-klimatycznych w Polsce. Prz. Met. Hydr. 1, 7-20. (In Polish)

Gumiński, R., 1950: Ważniejsze elementy klimatu rolniczego Polski południowo-wschodniej. Wiadomości Stużby Hydrologicznej i Meteorologicznej, 3, 57-113. (In Polish)

Hess, M., 1965: Piętra klimatyczne w Polskich Karpatach Zachodnich, Zesz. Nauk. UJ. Prace Geogr., 11. (In Polish)

Hiltunen, L., Haukka, J., Ruuhela, R., Suominen, K., and Partonen, T., 2014: Local daily temperatures, thermal seasons, and suicide rates in Finland from 1974 to 2010. Environ. Health. Prevent. Medic. 19, 286-294. https://doi.org/10.1007/s12199-014-0391-9

IMGW, 2000: Charakterystyka wybranych elementów klimatu Tarnowa, IMGW- Kraków. (In Polish)

Jaak, J., and Rein, A., 2000: Space-time variations of climatic seasons and their correlation with the phenological development of nature in Estonia. Climate Res. 15, 207-219. https://doi.org/10.3354/cr015207

Kondracki J., 2002: Geografia regionalna Polski, PWN, Warszawa. (In Polish)

Kwaśniewska, E. and Pereyma J., 2004: Termiczne Pory roku w Hondurasie (SW Spitsbergen), Problemy Klimatologii Polarnej 14, 157-169. (In Polish)

Lorenc, $H$. (ed.), 2005: Atlas klimatu Polski. IMGW, Warszawa. (In Polish)

Makowiec, M., 1983: Wyznaczanie termicznych pór roku. Pr. Geofizyc. 28, 209-220.(In Polish)

Merecki, M., 1915: Klimatologia ziem Polskich, Księgarnia Gebethnera i Wolffa, Warszawa. (In Polish)

Niedźwiedź, T., and Limanówka, D., 1992: Termiczne pory roku w Polsce. Zesz. Nauk. Uniw. Jagiell. Pr. Geogr. 90., 53-69. (In Polish)

Nowak, M., 1967: Termiczne pory roku na obszarze województwa olsztyńskiego, Zesz. Geogr. WSP w Gdańsku, R. 9, 257-266. (In Polish)

Nowosad, M. and Filipiuk, E., 1998: Zmiany czasu trwania termicznych pór roku w Lublinie w latach 1951-1995, Acta Universittatica Lodziensis. Folia Geographica Physica 3. (In Polish)

Piotrowicz, K., 2000: Zróżnicowanie termicznych pór roku w Krakowie, Prace Geograficzne., UJ Kraków, z. 105, 112-122. (In Polish)

Rapp, J. and Schönwiese, C.D., 1994: "Thermishe jahreszeiten" als anschauliche Charakteristik klimatischer Trends. Meteorol. Z. 3, 91-94. (In German)

Romer, E., 1906: Zimia. Geografia fizyczna ziem polskich. In]Polska Obrazy i Opisy, t. 1, Wydawnictwo Macierzy Polskiej. (In Polish)

Romer, E., 1938: Pogląd na klimat Polski. Czas. Geogr., t. 16, 193-224, also Wybór prac, t. III PTG/ PWN, Warszawa 1962, 389-361. (In Polish)

Ruosteenoja, K., Räisänen, J., and Pirinen, P., 2011: Projected changes in thermalseasons and the growing season in Finland. Int. J. Climatol. 31, 1473-1487. https://doi.org/10.1002/joc.2171

Samborski, A. and Bednarczuk, J., 2009: Termiczne pory roku w okolicach Zamościa w latach 20012008. Acta Agrophysica 14, 187-194. (In Polish)

Skowera, B. and Kopeć, 2008: Okresy termiczne w Polsce Południowo-Wschodniej (1971-2000). Acta Agrophysica 12, 517-526. (In Polish)

Stopa, M., 1968: Temperatura powietrza w Polsce, Dokumentacja Geograficzna 2, PAN, Warszawa. (In Polish)

Trybowska, E., 1963: Klimatologiczne pory roku w Rabce Zdroju, Przegl. Geofiz., R. 8, 151-154. (In Polish)

Woś, A., 1999: Klimat Polski, PWN, Warszawa. (In Polish)

Wiszniewski W., 1960: Kilka uwag o meteorologicznych porach roku w Polsce w świetle średnich wieloletnich wartości temperatury, Prz. Geofizycz. 5, 31-39. (In Polish) 